\title{
MASS BALANCE OF RHONEGLETSCHER DURING 1882/83-1986/87
}

\author{
By JiYAng Chen and Martin Funk \\ (Geographisches Institut and Versuchsanstalt für Wasserbau, Hydrologie und Glaziologie,
}

Eidgenössische Technische Hochschule, CH-8092 Zürich, Switzerland)

ABSTRACT. The glaciological investigations on Rhonegletscher were started in 1874. The mass-balance data measured during 1884/85-1908/09 and during 1979/80$1981 / 82$ are presented. Two methods are used for estimating the mass changes. During $1882 / 83-1968 / 69$, the cumulative specific net balance is $-24 \pm 6 \mathrm{~m}$ w.e. at the $90 \%$ confidence level by the regression model of annual mass balance, annual precipitation, and summer air temperature (the PT model), while the thickness change revealed by the maps is $-23 \pm 5 \mathrm{~m}$ w.e. The cumulative specific net balance during $1882 / 83-1986 / 87$ is $-26 \pm 6 \mathrm{~m}$ w.e. at the $90 \%$ confidence level.

The study shows that Rhonegletscher generally experienced mass loss, especially during the periods from the late 1920s through the early 1960 s with some short periods of positive balance. The glacier tongue retreated by $970 \mathrm{~m}$ during $1882-1986$, that is, from $1780 \mathrm{~m}$ a.s.l. (1882) to $2130 \mathrm{~m}$ a.s.l. (1986). During 1882-1969, the ice-covered area decreased by $4.37 \mathrm{~km}^{2}$ and the volume by $4.71 \times 10^{8} \mathrm{~m}^{3}$.

The PT models of Rhonegletscher and other alpine glaciers suggest that the contribution of the temperature changes to the mass balance is of more importance than that of the precipitation changes. The great mass loss reflects the climatic warming after the end of the Little Ice Age, with the warmest period occurring around the 1940s in this region.

\section{INTRODUCTION}

Mass balance of a glacier is a key element for understanding a glacier's behaviour and history. The processes of the mass exchange between snow/ice and the atmosphere are essential for knowing those of energy (heat) exchange associated with, and the effect of, snow/ice changes in the climatic systems (Ohmura, 1988). Mass balance also serves as an element of the water balance. Therefore, an accurate data base of the glacier mass balance both measured and reconstructed becomes essential (Martin, 1978; Tangborn, 1980; Reynaud and others, 1986).

Rhonegletscher is located in the middle of the Swiss Alps (lat. $46^{\circ} 37^{\prime} \mathrm{N}$., long. $08^{\circ} 24^{\prime} \mathrm{E}$.). It is the source of the Rhone River. This valley glacier is $10.2 \mathrm{~km}$ long with an area of $17.38 \mathrm{~km}^{2}$, and the terminus was at $2140 \mathrm{~m}$ a.s.l. in 1969 (Müller and others, 1976). The exposure of both the accumulation and ablation areas is to the south. Its mean thickness is about $100 \mathrm{~m}$ (Haeberli and others, 1983; Waechter, unpublished).

In this paper, the mass-balance data of Rhonegletscher measured during 1884/85-1908/09 (Mercanton, 1916) and during 1979/80-1981/82 (Funk, 1985) are presented. Furthermore, the mass change of Rhonegletscher since $1882-83$ is estimated by using a regression model of the specific net balance, the precipitation, and the air temperature (the PT model). To check the accuracy of the model, the results are compared with the mean thickness change of the glacier during 1882-1969 as revealed by the topographical maps. The PT models and the vertical gradients of the net balance of this glacier are analyzed in relation to the mass changes. Finally, the climatic implications of the mass changes of this glacier are briefly discussed.

\section{An overview of the studies on Rhonegletscher}

Rhonegletscher is one of the glaciers with the longest record of terminus fluctuations in the world and it still serves as a reference glacier for monitoring by the "Glacier Commission" (Gletscher-Kommission) of the Swiss Academy of Natural Sciences (SANW, earlier known as SNG Schweizerische Naturforschende Gesellschaft) and the World Glacier Monitoring Service.

The record of the fluctuations of Rhonegletscher goes back to 1869. In 1874, Rhonegletscher was selected for systematic glaciological studies by the "Glacier Committee" (Gletscher-Kollegium) of the SANW and of the Swiss Alpine Club (SAC). The aim of the study at that time was to understand the historical development of the glacier and its flow, as well as the waxing and waning of the glacier due to the changes occurring at the glacier surface. The studies covered: (1) topographical survey of changes of the ice surface and the tongue, (2) ablation and accumulation, (3) glacier flow, (4) glacier run-off, and (5) the structures of the glacier. The main studies were funded and guided by the Glacier Committee during 1874-88, and the Glacier Commission during 1888-1915. The measurements were done by $\mathrm{P}$. Gosset during 1874-80, L. Held during 1881-88, and L. Held, H. Wild, S. Simonett, and E. Leupin during 18881915. Some of the research reports were published (Rütimeyer, 1880-81, 1881-84, 1886-88; Coaz, 1885; Hagenbach-Bischoff, 1894-1910; Heim, 1910-15; Held, 1889). The results were summarized by Mercanton (1916).

The fluctuations of this glacier have been monitored continuously by the Glacier Commission (Kasser and Aellen, 1986). A new comprehensive glaciological, climatological, and hydrological research project on Rhonegletscher (Rhonegletscher Project) was initiated in 1979 by the Department of Geography of the Swiss Federal Institute of Technology (ETH Zürich) with the aim of studying the combined balances of ice, water, and energy in a strongly glacierized basin (Müller and others, 1980). The mass-balance study was a part of this project in which both winter balance and summer balance of the glacier had been measured (Funk, 1985). Other studies on Rhonegletscher concerned the ablation gradient (Haefeli, 1962), radio-echo sounding (Haeberli and others, 1983; Waechter, unpublished), hydrology (Bernath, unpublished), length variations (Kasser and Aellen, 1986; Müller, 1988), and the mechanical characteristics of the historical glacier in 1850 (Haeberli and Schweizer, 1988). A general survey of this glacier has been given by Röthlisberger (1963). 
Maps

The first topographic map of Rhonegletscher was made by $\mathrm{H}$. Siegfried and L. Held between 1874 and 1882. The tongue was drawn at a scale of $1: 5000$, and the rest of the glacier at a scale of $1: 25000$, with a contour interval of $10 \mathrm{~m}$ (Mercanton, 1916). In 1959 and 1969, Rhonegletscher was mapped again at a scale of $1: 25000$ and with a contour interval of $20 \mathrm{~m}$. It was printed on two sheets; Guttannen (Map No. 1230, 1969) and Urseren (Map No. 1231, 1959) of the Swiss Federal Topographical Survey. The accuracy of the topographical maps of the glacier is within $\pm 5 \mathrm{~m}$ (better in the lower ablation area than in the upper accumulation area).

\section{MASS-BALANCE DATA}

\section{Mass-balance measurements}

The following profiles were established for the velocity, elevation, and mass-change measurements (Fig, 1): four in

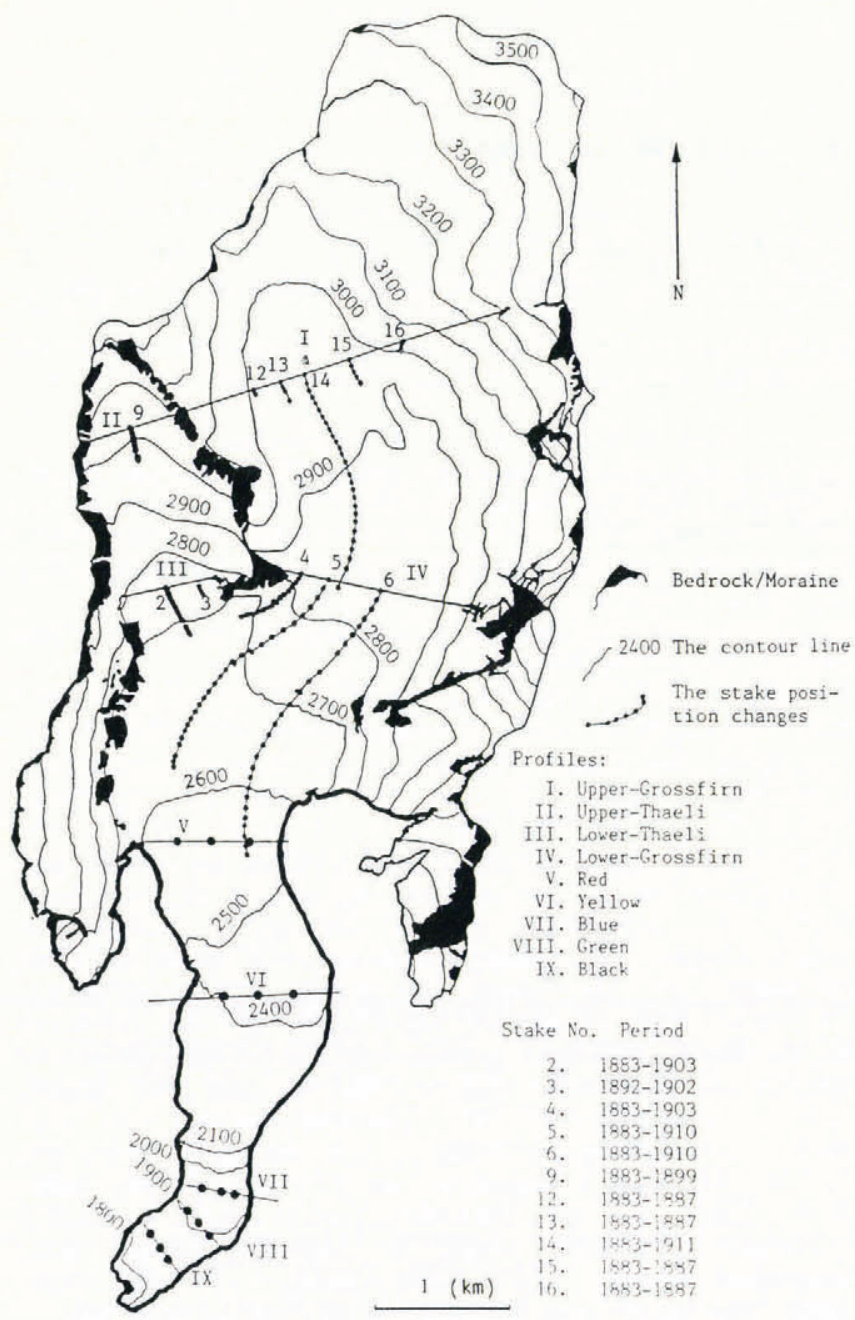

Fig. 1. A sketch showing the profiles and the stakes for mass-balance measurements during 1884/85-1908/09. reduced after Mercanton (1916, pl. I).

1874-75 called black, green, yellow, and red; another four in 1881-82 (Upper- and Lower-Grossfirn and Upper- and Lower-Thaeli), and one in 1895 (blue). Due to glacier retreat, the lowest three profiles disappeared in 1882-83, 1899-1900, and 1911-12.

For the period $1884 / 85-1909 / 10$, the mass changes were measured by observing ablation and/or accumulation using stakes. The changes in the surface elevation only were measured without density determinations. The positions of the stakes of the upper four profiles are shown in Figure 1. More than 11 stakes were installed in the profiles I-IV, but these stakes moved with time and some even disappeared. There are three stakes for each of the profiles
V-IX, which were newly installed each year at the initial profile positions.

The annual mass change was defined as "accumulation" when the glacier had gained mass during a hydrologic year and as "ablation" when mass was lost. The original data for ablation or accumulation should be translated into the specific annual balance or the specific net balance by the fixed date system, as defined by Meier (1963), Østrem and Stanley (1966), and Mayo and others (1972).

For the period $1979 / 80-1981 / 82$, measurements of mass balance were made by Funk (1985) at 50 points selected so as to provide a good representation of the spatial mass-balance distribution (Fig. 2). The data were analyzed by a multiple-regression model to discover the relationships between the specific net balance and the morphological parameters of the glacier surface.

\section{Calculation of the specific net balance}

In the present approach, annual net balance of a point as measured by a stake will be denoted as $b$ while the

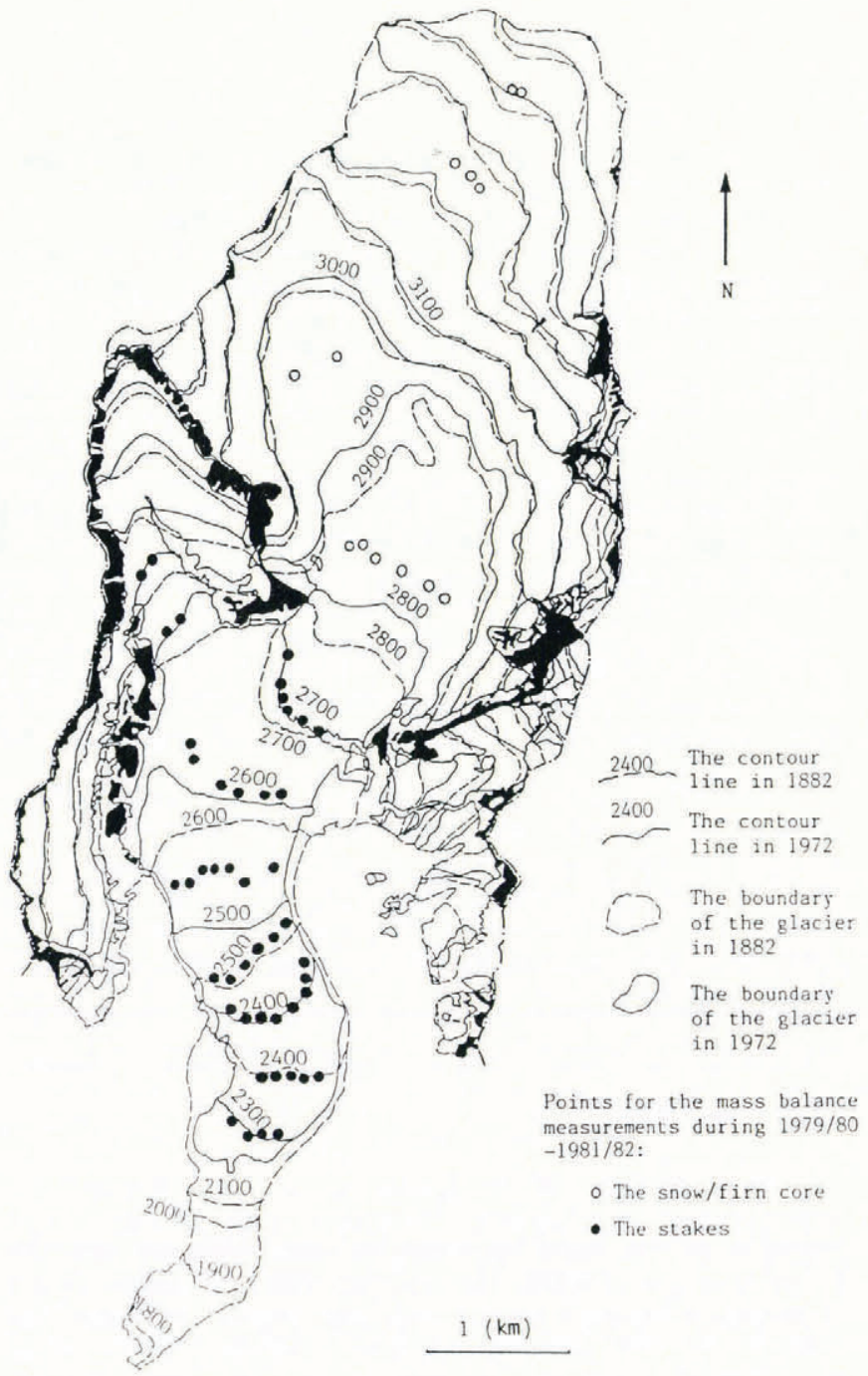

Fig. 2. Positions for mass-balance measurements during 1979/80-1981/82 and comparison of the contour lines in 1882 and 1969 for Rhonegletscher.

specific annual net balance over an area (an altitude interval, the ablation area, the accumulation area, or the whole glacier) is specified as $\langle b\rangle$. \langle\rangle specifies the mean of $b$ over the whole area. To calculate the mean specific net balance $\langle b\rangle$ of a glacier, the commonly applied formula is

$$
\langle b\rangle=(1 / S) \sum_{i=1}^{N}\langle b\rangle_{i} s_{i}
$$

where $s_{i}$ is the area of the glacier within the $i$ th altitude interval of $100 \mathrm{~m}$, and $\langle b\rangle_{i}$ is the specific net balance of that interval. 
When calculating $\langle b\rangle$ with Equation $(1),\langle b\rangle_{i}$ can be approximated as the arithmetic mean of the $b$ values of the stakes in the $i$ th altitude interval. $s_{i}$ changes from year to year, especially in the ablation area, but it is not measured annually in most cases. By taking $s_{i}$ as the area of the glacier or as that of the ice-covered area (i.e. including the area of small ice patches in the same altitude interval, which are separated from the glacier), some differences in the calculation of $\langle b\rangle$ may be introduced. The ice-covered area is used for the $\langle b\rangle$ calculation for the period $1884 / 85-1908 / 09$ while the glacier area is used for the calculation of $\langle b\rangle \quad 1979 / 80-1981 / 82$. For Rhonegletscher in 1969 , the glacier area was $17.38 \mathrm{~km}^{2}$ and the ice-covered area was $18.42 \mathrm{~km}^{2}$. This is a difference of $1.04 \mathrm{~km}^{2}$. No corrections were made for this and the resultant error is judged to be small. In the present study, "area" always refers to "ice-covered area".

\section{Correction of the 1884/85-1908/09 mass-balance data}

The original data are point values of stake measurements giving ablation or accumulation. They need to be corrected before they can be used for the following reasons: (1) the length of the annual measurement period changed with time, (2) the position of the stakes changed with time, (3) the snow/firn densities are unknown, and (4) in some areas of the glacier, there are no measurements.

The times of stake readings for mass-balance measurements varied from late August to late September. Therefore, part of the original records of mass balance shows a time deviation of about 1 month, by the end of a hydrological year, from the period of the generally used hydrological year (the fixed-date system) in the midlatitudes (beginning of October-end of September). The time deviations introduced some errors to the calculation of $\langle b\rangle$ for the years when intense ablation or accumulation occurred by the end of the year and were not considered.

Stake position. The stakes were used for the simultaneous measurements of both ice flow and mass balance. In the lower part of the glacier they had to be replaced or newly installed due to ice flow and intense ablation. Therefore, the coordinates of the stakes or observation points changed with time. This can easily be considered by using the information on the positions of the measurement points as given by Mercanton (1916).

Densities of snow/firn/ice. Densities of snow/firn/ice are basic data for mass-balance calculations, especially in the accumulation area. As no original density measurements are available, the data are treated in the following way: the positive mass-balance data (almost all stakes with positive $b$ in the accumulation area) are multiplied by a constant of 0.6 (the mean density of firn), according to the field measurements on Rhonegletscher by Funk (1985), and the negative mass balance in the ablation area by 0.9 (the density of ice).

Data extrapolation. Above the two "upper" profiles in the accumulation area, there are about four $100 \mathrm{~m}$ altitude intervals which extend from 3200 to $3629 \mathrm{~m}$ a.s.l. and covered $4.28 \mathrm{~km}^{2}$ in $1874-82(18.8 \%$ of the total area). Their area remained almost unchanged until 1930. For this area, $\langle b\rangle$ values are extrapolated using a vertical gradient of $\langle b\rangle$ (hereafter referred to as $\langle\mathrm{d} b / \mathrm{d} z\rangle$ ) of $6.3 \mathrm{~mm} / \mathrm{m}$ which is the mean gradient for the accumulation area measured during the period 1979/80-1981/82 (Table I). In some years, the stakes were lost in the lower part of the tongue due to strong ablation. For example, the mass-balance data for the five altitude intervals between $2600 \mathrm{~m}$ a.s.1. and the terminus $(1780 \mathrm{~m}$ a.s.1.) were lost in 1884-85. Missing data from the ablation area are extrapolated according to the mass-balance data of neighbouring altitude intervals and $\langle\mathrm{d} b / \mathrm{d} z\rangle$ for that year or $9.1 \mathrm{~mm} / \mathrm{m}$, which is the mean value for the ablation area during the period 1979/80-1981/82 (Table I) in the case (1884-85) where $b$ data are insufficient for calculating $\mathrm{d} b / \mathrm{d} z$. The year with only a few measurement points is not used for the caculation (1909-10). The reason for using the given values of $\langle\mathrm{d} b / \mathrm{d} z\rangle$ will be discussed in the following section.

\section{Analysis of the measured mass-balance data}

The data for the measured $\langle b\rangle$ versus the altitude interval, compiled as explained above based on the original data (Mercanton, 1916), are listed in Table II. Despite the fact that the vertical gradient of $\langle b\rangle$ is larger in the lower part of the ablation area and becomes smaller towards the accumulation area, the maximum amplitude of the vertical shift in $\langle b\rangle$-isolines can be observed in the altitude interval where the equilibrium line appears (Fig. 3). The amplitude of the vertical shift of the $\langle b\rangle=0 \mathrm{~m}$ w.e. isoline is $500 \mathrm{~m}$ (2600-3100 $\mathrm{m}$ a.s.1.). Moreover, it is larger in the accumulation area than in the ablation area.

The specific net balance $\langle b\rangle$ during 1884/85-1908/09 and 1979/70-1981/82 (Funk, 1985) and some other data from Rhonegletscher are listed in Table I. The mass balance for the period $1884 / 85-1908 / 09$ is generally negative, and the cumulative $\langle b\rangle$ during those 25 years is $-3240 \mathrm{~mm}$ w.e. Some short periods with a positive $\langle b\rangle$ occurred in the late $1880 \mathrm{~s}$, the mid-1890s, and the late 1900s.

For the period $1979 / 80-1981 / 82$, the specific summer balance of Rhonegletscher is $-1350 \mathrm{~mm}$ w.e. in its accumulation area and $-3800 \mathrm{~mm}$ w.e. in the ablation area. The specific winter balance is $2610 \mathrm{~mm}$ w.e. in the accumulation area and $1660 \mathrm{~mm}$ w.e. in the ablation area. The specific net balance $\langle b\rangle$ (in $\mathrm{mm}$ w.e.) of Rhonegletscher was 890 in $1979-80,90$ in $1980-81$, and -380 in 1981-82.

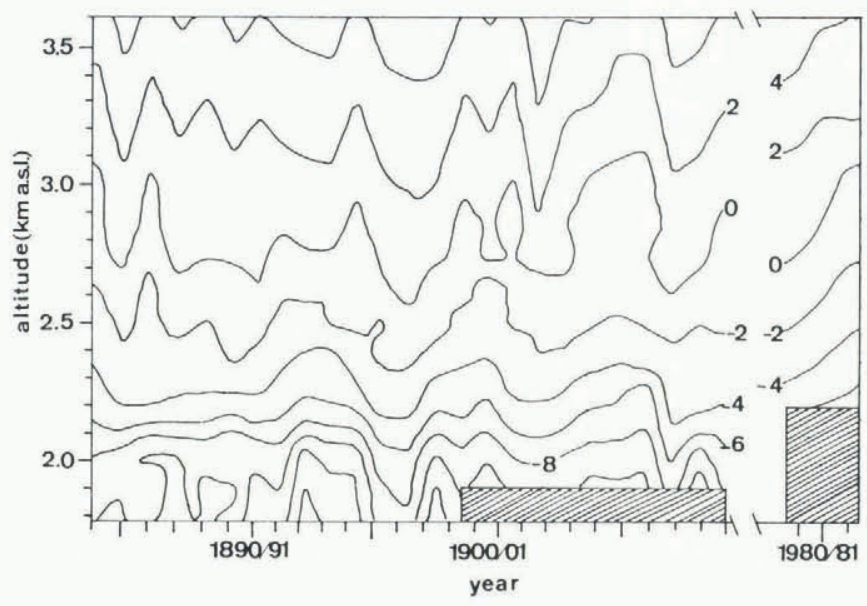

Fig. 3. Changes of specific net balance (in $m$ w.e.) with altitude and time for Rhonegletscher during 1884/85-1908/09 and 1979/80-1981/82.

THE VERTICAL GRADIENT OF THE SPECIFIC NET BALANCE

The vertical gradient of the specific net balance $\langle\mathrm{d} b / \mathrm{d} z\rangle$ reflects the net balance change with altitude or the form of the specific net balance-elevation curve $\left(\langle b\rangle_{-z}\right.$ curve). For some glaciers the $\langle b\rangle-z$ curves for different years have a similar form, i.e. the $\langle b\rangle-z$ curve for a glacier for one year can be approximated by a parallel displacement of the $\langle b\rangle-z$ curve of that glacier of the reference year (Meier and Tangborn, 1965; Hoinkes, 1970). This reference $\langle b\rangle-z$ curve is usually taken as the mean $\langle b\rangle-z$ curve or the $\langle b\rangle-z$ curve for the near-balance situation. If such a feature applies universally, it implies that mass-balance measurement field work could be reduced. The $\langle b\rangle-z$ curve for Rhonegletscher also shows this feature for the years 1979-80, 1980-81, and 1981-82 (Fig. 4). However, detailed examination shows that the vertical gradient of the mass balance of Rhonegletscher is not strictly a constant in time.

The spatial distribution of $b$ values of Rhonegletscher during 1979/80-1981/82 has been investigated by Funk (1985) using multiple-regression analysis with morphological parameters of the glacier surface (elevation, surface slope, azimuth, and concavity and convexity index) as independent variables. These morphological variables have been 
TABLE I. SPECIFIC NET BALANCE $\langle b\rangle$ (IN mm w.e.), EQUILIBRIUM LINE ALTITUDE ELA (IN ma.s.1.), AND VERTICAL GRADIENT OF MASS BALANCE $\langle\mathrm{d} b / \mathrm{d} z\rangle$ (IN $\mathrm{mm} w . e . / \mathrm{m}$ ) OF RHONEGLETSCHER

\begin{tabular}{|c|c|c|c|c|c|c|c|c|}
\hline Year & $\langle b\rangle$ & $E L A$ & $\begin{array}{l}\langle\mathrm{d} t \\
(1)\end{array}$ & $\begin{aligned} & \mathrm{d} z>\mathrm{g} \\
&(2)^{2}\end{aligned}$ & $\begin{array}{l}\langle\mathrm{d} b \\
(1)\end{array}$ & $\begin{aligned} & \mathrm{d} z>\mathrm{a} \\
&(2)^{2}\end{aligned}$ & ${ }_{(1)}^{<d}$ & $\begin{array}{l}\mid z>c \\
(2)\end{array}$ \\
\hline $1884-85$ & -1210 & 3124 & 7.4 & 6.9 & 7.8 & 7.3 & 6.6 & 6.6 \\
\hline $1885-86$ & 590 & 2812 & 8.3 & 8.5 & 10.6 & 9.6 & 6.6 & 5.5 \\
\hline $1886-87$ & -1160 & 3098 & 5.7 & 6.7 & 5.5 & 6.9 & 6.6 & 6.9 \\
\hline $1887-88$ & 910 & 2795 & 9.6 & 10.0 & 11.8 & 11.4 & 7.4 & 6.8 \\
\hline $1888-89$ & -270 & 2845 & 6.4 & 7.1 & 7.8 & 7.9 & 5.5 & 4.6 \\
\hline $1889-90$ & 280 & 2830 & 6.8 & 7.9 & 7.6 & 8.7 & 6.5 & 5.9 \\
\hline $1890-91$ & 140 & 2772 & 8.1 & 8.9 & 11.0 & 10.9 & 4.9 & 4.4 \\
\hline $1891-92$ & -360 & 2920 & 8.6 & 8.5 & 9.9 & 9.1 & 7.2 & 7.3 \\
\hline $1892-93$ & -340 & 2872 & 10.3 & 11.1 & 12.6 & 13.0 & 6.6 & 6.6 \\
\hline $1893-94$ & -500 & 2869 & 9.2 & 9.6 & 11.4 & 11.2 & 5.3 & 5.4 \\
\hline $1894-95$ & -860 & 3018 & 8.9 & 9.3 & 10.0 & 10.5 & 7.0 & 7.4 \\
\hline $1895-96$ & 740 & 2804 & 8.0 & 7.7 & 9.1 & 8.1 & 6.8 & 6.5 \\
\hline $1896-97$ & 920 & 2726 & 7.6 & 7.2 & 9.1 & 7.7 & 6.1 & 6.3 \\
\hline $1897-98$ & 370 & 2825 & 9.8 & 10.0 & 12.5 & 11.5 & 7.4 & 6.3 \\
\hline $1898-99$ & -380 & 2920 & 8.3 & 8.1 & 9.5 & 8.6 & 6.5 & 6.5 \\
\hline $1899-00$ & -420 & 2838 & 8.7 & 9.3 & 11.7 & 10.4 & 5.9 & 5.7 \\
\hline $1900-01$ & -600 & 3029 & 6.9 & 7.1 & 7.2 & 7.7 & 4.9 & 5.7 \\
\hline $1901-02$ & 380 & 2833 & 7.8 & 8.2 & 9.2 & 8.9 & 5.6 & 6.3 \\
\hline $1902-03$ & 150 & 2791 & 7.3 & 7.6 & 9.3 & 8.6 & 4.2 & 5.2 \\
\hline $1903-04$ & -710 & 3003 & 8.0 & 8.4 & 8.9 & 9.3 & 4.9 & 6.6 \\
\hline $1904-05$ & -1190 & 3105 & 7.8 & 8.0 & 8.2 & 8.5 & 5.1 & 7.0 \\
\hline $1905-06$ & -980 & 3075 & 8.1 & 8.4 & 8.8 & 9.4 & 4.7 & 6.0 \\
\hline $1906-07$ & 760 & 2795 & 6.9 & 6.9 & 7.4 & 7.1 & 5.2 & 6.3 \\
\hline $1907-08$ & 320 & 2811 & 8.0 & 8.8 & 10.1 & 10.1 & 5.1 & 5.9 \\
\hline $1908-09$ & 170 & 2926 & 7.2 & 7.3 & 7.7 & 7.5 & 5.1 & 7.4 \\
\hline $\begin{array}{l}\text { Mean } \\
(1884 / 85-1908 / 0\end{array}$ & $\begin{array}{l}-130 \\
09)\end{array}$ & 2897 & 8.0 & 8.2 & 9.4 & 9.2 & 5.9 & 6.1 \\
\hline $1979-80$ & 890 & 2764 & 9.1 & 7.0 & 12.4 & 9.9 & 5.7 & 6.3 \\
\hline $1980-81$ & 90 & 2875 & 8.7 & 6.7 & 10.5 & 8.8 & 5.8 & 6.4 \\
\hline $1981-82$ & -380 & 3035 & 8.7 & 7.4 & 9.8 & 8.6 & 6.7 & 7.1 \\
\hline $\begin{array}{l}\text { Mean } \\
(1979 / 80-1981 / 8\end{array}$ & $82)^{200}$ & 2890 & 8.8 & 7.1 & 10.9 & 9.1 & 6.1 & 6.3 \\
\hline
\end{tabular}

The subscripts for $\langle\mathrm{d} b / \mathrm{d} z\rangle$, a, c, and $\mathrm{g}$, specify the ablation area, the accumulation area, and the entire glacier. (1) and (2) denote that corresponding $\mathrm{d} b / \mathrm{d} z$ are calculated by Equations (2) and (3), respectively.

determined with a digital elevation model. It has been shown that the most suitable morphological variables for expressing the spatial distribution of the mass balance are the elevation and slope of the surface.

The values of $\langle\mathrm{d} b / \mathrm{d} z\rangle$ for Rhonegletscher are calculated in two ways, first by:

$$
\left.\langle\mathrm{d} b / \mathrm{d} z\rangle_{i}=\left(\langle b\rangle_{i+1}-\langle b\rangle_{i-1}\right) / z_{i+1}-z_{i-1}\right)
$$

where $\langle b\rangle$ is defined as above and $z$ is the altitude. The subscript $i$ denotes the $i$ th altitude interval. The mean $\langle\mathrm{d} b / \mathrm{d} z\rangle$ of the ablation and accumulation areas, as well as the entire glacier, which are referred to as $\langle\mathrm{d} b / \mathrm{d} z\rangle_{\text {, }}$, $\langle\mathrm{d} b / \mathrm{d} z\rangle_{\mathrm{C}}$, and $\langle\mathrm{d} b / \mathrm{d} z\rangle_{\mathrm{g}}$, respectively, is the arithmetic mean over all the altitude intervals in the corresponding area. The second method is to find a linear regression relationship between the specific net balance $\langle b\rangle_{i}$ and the altitude $z_{i}$ :

$$
\langle b\rangle_{i}=\beta_{0}+\beta_{1} z_{i} .
$$

If the correlation of $\langle b\rangle_{i}-z_{i}$ is significant, the value of $\beta_{1}$ can be taken as that of $\langle\mathrm{d} b / \mathrm{d} z\rangle$.

Both Equations (2) and (3) are used for calculating $\langle\mathrm{d} b / \mathrm{d} z\rangle_{a},\langle\mathrm{~d} b / \mathrm{d} z\rangle_{c}$, and $\langle\mathrm{d} b / \mathrm{d} z\rangle_{\mathrm{g}}$ for Rhonegletscher. The $\langle\mathrm{d} b / \mathrm{d} z\rangle$ values calculated by Equation (3) agree with those calculated by Equation (2) for the years when the $\langle b\rangle$ curves do not deviate much from the linear form (Table I). It can be seen from the data for 1979/80-1981/82 that the value of $\langle\mathrm{d} b / \mathrm{d} z\rangle_{\mathrm{a}}$ is usually different from that of $\langle\mathrm{d} b / \mathrm{d} z\rangle_{\mathrm{c}}$. It follows that extrapolation of missing $b$ values should be done by using $\langle\mathrm{d} b / \mathrm{d} z\rangle_{c}$ for the accumulation area and $\langle\mathrm{d} b / \mathrm{d} z\rangle_{\mathrm{a}}$ for the ablation area. Although the results suggest that annual $\langle\mathrm{d} b / \mathrm{d} z\rangle$ changes with time, the mean of $\langle\mathrm{d} b / \mathrm{d} z\rangle$ over a long time remains stable $(7-9 \mathrm{~mm} / \mathrm{m}$ for the entire glacier, $9-10 \mathrm{~mm} / \mathrm{m}$ for its ablation area, and about $6 \mathrm{~mm} / \mathrm{m}$ for its accumulation area). The $\langle\mathrm{d} b / \mathrm{d} z\rangle$ values from the measurements during 1979/80$1981 / 82$, covering the whole glacier, are considered to be relatively accurate and are therefore used for extrapolation purposes.

\section{MEAN ELEVATION CHANGES}

Changes in elevation and volume of glaciers can be determined by using the digital elevation model or the contour method (Finsterwalder, 1954; Reinhardt and Rentsch, 1986). Both methods are used here.

Method I. The topographical maps $(1: 25000)$ completed during 1874-82 and in 1969 have been digitized by hand with a grid-point interval of $100 \mathrm{~m}$ in order to obtain the elevation change $\langle\Delta h\rangle$ of Rhonegletscher during 1882-1969. The accuracy of the elevation is estimated to be within $\pm 5 \mathrm{~m}$ for each grid point. $\langle\Delta h\rangle$ of Rhonegletscher during $1882-1969$ is obtained from the $\Delta h$ of all grid points. The area change is determined by planimetry. The results are given in Table III and shown in Figure 5. Elevation changes are mapped in Figure 6. Areas with intensive shrinkage during 1882-1969 include the central and lower parts of the glacier. $\langle\Delta h\rangle$ of the ice surface during 
TABLE II. SPECIFIC NET BALANCE IN $100 \mathrm{~m}$ ALTITUDE INTERVALS OF RHONEGLETSCHER FOR THE PERIODS 1884/85-1908/09 AND 1979/80-1981/82

Altitude interval

m a.s.l.

$\begin{array}{ccccccccccc} & & 1884-85 & 85-86 & 86-87 & 87-88 & 88-89 & 89-90 & 90-91 & 91-92 & 92-93 \\ 3500 & 3629 & (276) & (477) & (299) & (570) & (345) & (450) & (381) & (432) & (456) \\ 3400 & 3500 & (213) & (414) & (236) & (507) & (282) & (387) & (318) & (369) & (393) \\ 3300 & 3400 & (150) & (351) & (173) & (444) & (219) & (324) & (255) & (306) & (330) \\ 3200 & 3300 & (87) & (288) & (110) & (381) & (156) & (261) & (192) & (243) & (267) \\ 3100 & 3200 & (24) & (225) & (47) & (318) & (93) & (198) & (129) & (180) & (204) \\ 3000 & 3100 & -67 & 162 & -44 & 255 & 30 & 135 & 66 & 117 & 141 \\ 2900 & 3000 & -76 & 192 & -113 & 192 & 108 & 114 & 144 & 54 & 78 \\ 2800 & 2900 & -84 & 64 & -182 & (75) & (8) & (24) & (65) & -129 & (-22) \\ 2700 & 2800 & -216 & -105 & -251 & -61 & -140 & -97 & -18 & -171 & -161 \\ 2600 & 2700 & (-298) & (-166) & -245 & (-155) & (-210) & (-129) & (-130) & (-261) & (-287) \\ 2500 & 2600 & (-380) & (-266) & -239 & (-248) & (-285) & -161 & -242 & -350 & -413 \\ 2400 & 2500 & (-462) & -287 & -233 & -341 & -359 & (-361) & -337 & (-453) & -521 \\ 2100 & 2400 & (-585) & (-500) & (-554) & (-595) & (-582) & (-661) & (-561) & (-607) & (-808) \\ 1900 & 2100 & (-790) & -854 & -1016 & -953 & -935 & -863 & (-1286) & -863 & -1286 \\ 1800 & 1900 & (-913) & (-977) & -728 & (-1139) & -706 & -755 & (-1058) & (-986) & (-1409) \\ 1789 & 1800 & (-994) & (-1059) & (-810) & (-1221) & (-788) & (-837) & (-1140) & (-1068) & (-1491)\end{array}$

Annual specific net balance

cm w.e.

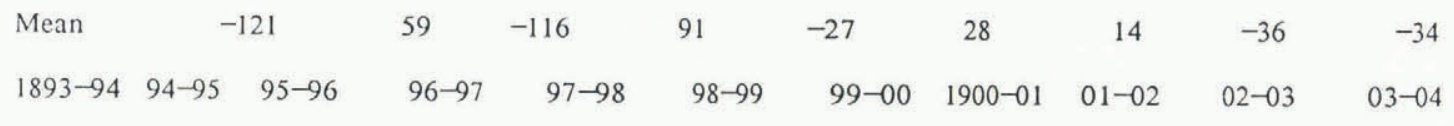

$\begin{array}{ccccccccccc}(375) & (374) & (511) & (503) & (501) & (405) & (411) & (334) & (473) & (401) & (358) \\ (312) & (311) & (448) & (440 & (438) & (342) & (348) & (271) & (410) & (338) & (295) \\ (249) & (248) & (385) & (377) & (375) & (279) & (285) & (208) & (347) & (275) & (232) \\ (186) & (185) & (322) & (314) & (312) & (216) & (222) & (145) & (284) & (212) & (169) \\ (123) & (122) & (259) & (251) & (249) & (153) & (159) & (82) & (221) & (149) & (106) \\ 60 & (29) & (196) & (188) & (186) & (90) & (96) & (19) & (158) & (86) & (43) \\ 96 & -62 & (133) & (125) & (123) & 27 & 33 & -72 & 95 & 23 & -48 \\ (-23) & (-142) & (42) & 62 & 60 & -64 & 48 & -17 & 32 & 90 & -99 \\ -190 & -223 & -49 & 16 & -180 & -131 & -336 & -161 & -153 & -62 & -150 \\ -190 & -156 & -215 & -51 & -108 & -272 & -254 & -181 & -162 & -94 & -177 \\ -431 & -313 & -152 & -163 & -288 & -332 & -368 & -332 & -204 & -233 & -305 \\ -485 & -430 & (-255) & -253 & -450 & -476 & -548 & -353 & -348 & -368 & -521 \\ (-725) & (-690) & (-409) & (-386) & (-662) & (-602) & (-710) & (-511) & (-510) & (-523) & (-674) \\ -1124 & -1123 & (-665) & (-607) & (-1013) & (-810) & (-980) & (-773) & (-773) & (-778) & (-927) \\ (-1247) & (-1246) & -818 & -739 & -1224 & -935 & -1142 & -930 & -940 & -935 & -1079 \\ (-1329) & (-1328) & (-900) & (-820) & (-1306) & (-1017) & (-1225) & - & - & - & -\end{array}$

$\begin{array}{lllllllllll}-50 & -86 & 74 & 92 & 37 & -38 & -42 & -82 & 38 & 15 & -71\end{array}$

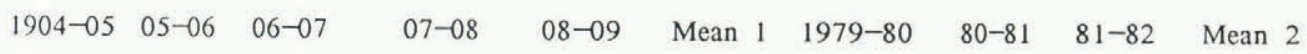

$\begin{array}{ccccccccrr}(321) & (320) & (495) & (456) & (451) & 415 & 476 & 392 & 375 & 414 \\ (258) & (257) & (432) & (393) & (388) & 352 & 431 & 332 & 328 & 364 \\ (195) & (194) & (369) & (330) & (325) & 289 & 355 & 259 & 250 & 288 \\ (132) & (131) & (306) & (267) & (262) & 226 & 318 & 230 & 210 & 253 \\ (41) & (68) & (243) & (204) & (199) & 162 & 203 & 124 & 106 & 144 \\ (-50) & (-23) & (180) & (141) & (136) & 93 & 110 & 43 & 5 & 53 \\ -141 & -114 & 117 & (78) & 26 & 45 & 90 & 21 & -28 & 28 \\ -111 & -29 & 54 & (67) & -84 & -12 & 79 & -8 & -67 & 1 \\ -143 & (-109) & (-45) & (-104) & (-113) & -134 & -13 & -103 & -164 & -93 \\ -218 & -188 & -144 & -195 & -142 & -185 & -81 & -170 & -240 & -164 \\ -364 & -269 & -229 & -265 & -329 & -284 & -143 & -213 & -298 & -219 \\ -557 & -692 & -269 & -224 & -313 & -396 & -250 & -304 & -390 & -315 \\ (-690) & (-793) & (-378) & (-480) & (-518) & -589 & -361 & -431 & -513 & -435 \\ (-911) & (-961) & (-559) & (-905) & (-641) & -896 & - & - & - & - \\ -1043 & -1061 & -667 & -1160 & (-732) & -993 & - & - & - & - \\ - & - & - & - & - & - & - & - & - & - \\ -119 & -98 & 76 & 32 & 17 & -13 & 89 & 9 & -38 & 20\end{array}$

Values in brackets are either interpolated or extrapolated.

Mean 1: the mean for $1884 / 85-1908 / 09$.

Mean 2: the mean for $1979 / 80-1981 / 82$. 

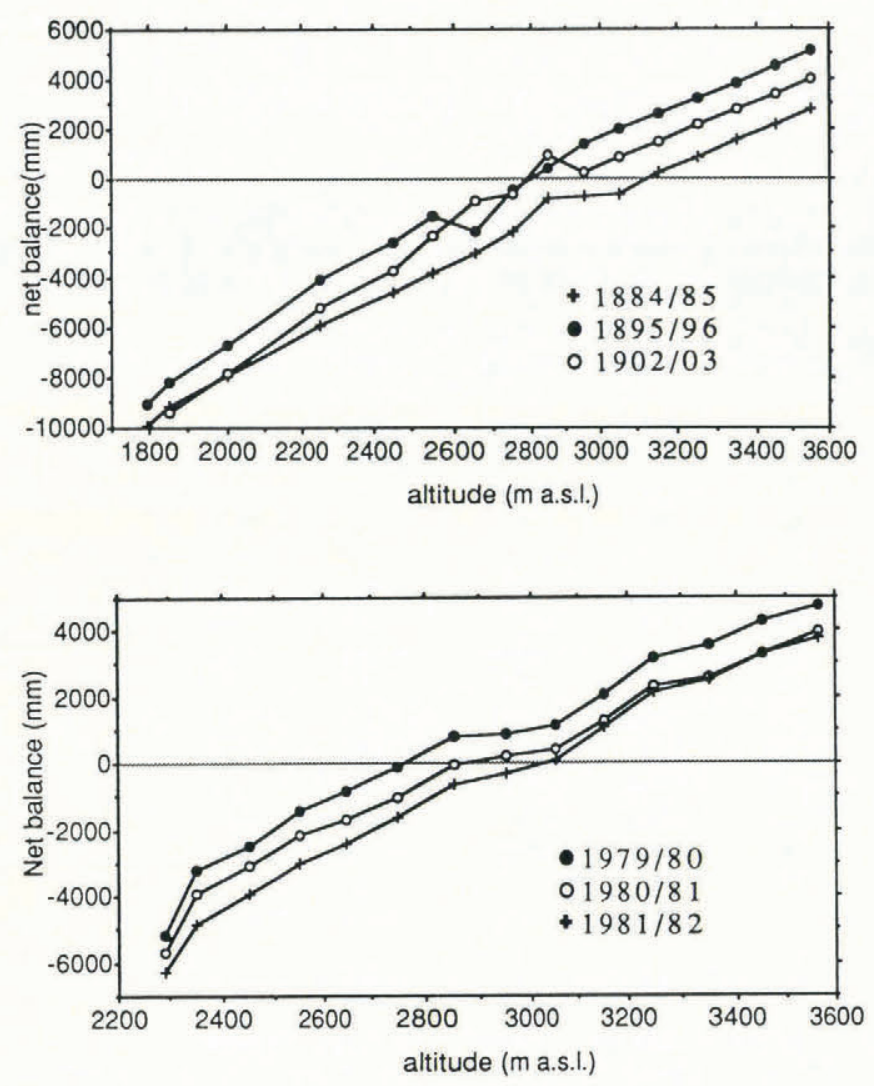

Fig. 4. Specific net balance versus altitude of Rhonegletscher for the years 1884-85, 1895-96, 1902-03, $1979-80,1980-81$, and 1981-82.

$1882-1969$ is $-20 \mathrm{~m}$ as revealed by two maps. The errors in the $\langle\Delta h\rangle$ estimation by method $\mathrm{I}$ is mainly introduced by the interpolation of the elevation of some grid points.

Method II. The thickness change $\langle\Delta h\rangle$ of the glacier can also be estimated as

$$
\langle\Delta h\rangle=\Delta V / \bar{S}
$$

where $\Delta V$ is the volume change and $\bar{S}$ the mean area of the glacier during the considered period. $\Delta V$ is equal to

$$
\Delta V=\sum_{i=1}^{N} \Delta V_{i}=\sum_{i=1}^{N} \Delta z_{i}\left(\Delta S_{i}+\Delta S_{i+1}\right) / 2
$$

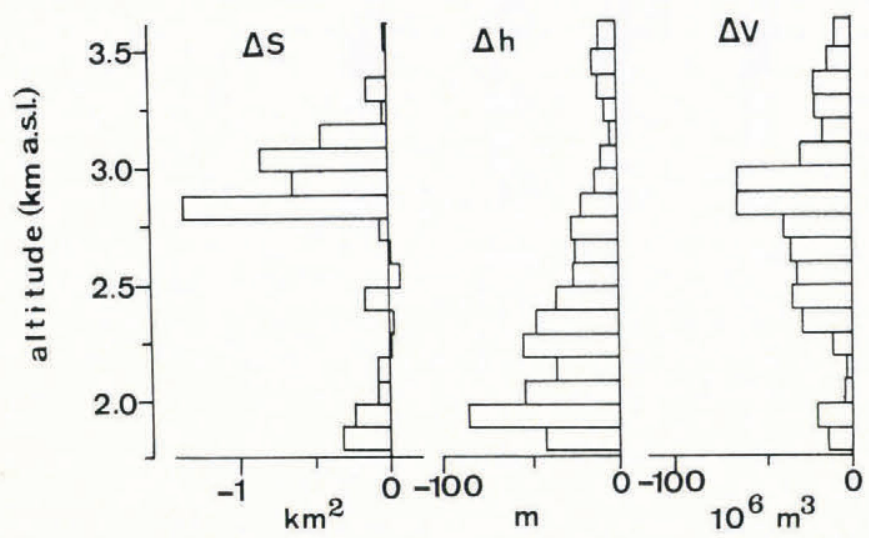

Fig. 5. Changes of ice-covered area and mean thickness of Rhonegletscher between 1882 and 1969. $\Delta S(1882-1969)$ : change of ice-covered area during 1882-1969; $\Delta h(1882-1969)$ : mean thickness change during 1882-1969; $\Delta V(1882-1969)$ : volume change during 1882-1969.
TABLE III. ICE-COVERED AREA $S\left(\right.$ IN $\left.\mathrm{km}^{2}\right)$ IN 1882 , CHANGES OF ICE-COVERED AREA $\triangle S$ (IN $\mathrm{km}^{2}$ ), AND MEAN CHANGES OF THE SURFACE ELEVATION $\langle\Delta h\rangle$ (IN m w.e.) IN $100 \mathrm{~m}$ ALTITUDE INTERVALS OF RHONEGLETSCHER FOR THE PERIOD 1882-1969

\begin{tabular}{llrrrr}
$H 1$ & $H 2$ & $S(1882)$ & \multicolumn{1}{c}{$\Delta S$} & $\langle\Delta h\rangle(1)$ & $\langle\Delta h\rangle(2)$ \\
3500 & 3629 & 0.47 & -0.05 & -10 & -22 \\
3400 & 3500 & 0.82 & 0.00 & -14 & -17 \\
3300 & 3400 & 1.32 & -0.13 & -11 & -18 \\
3200 & 3300 & 1.67 & -0.03 & -7 & -13 \\
3100 & 3200 & 2.11 & -0.46 & -4 & -9 \\
3000 & 3100 & 2.93 & -0.87 & -9 & -13 \\
2900 & 3000 & 3.51 & -0.65 & -13 & -22 \\
2800 & 2900 & 3.24 & -1.37 & -21 & -28 \\
2700 & 2800 & 1.54 & -0.06 & -27 & -27 \\
2600 & 2700 & 1.89 & 0.01 & -25 & -19 \\
2500 & 2600 & 0.99 & 0.07 & -26 & -31 \\
2400 & 2500 & 0.75 & -0.16 & -36 & -52 \\
2300 & 2400 & 0.69 & 0.03 & -48 & -41 \\
2200 & 2300 & 0.20 & 0.01 & -56 & -56 \\
2100 & 2200 & 0.08 & -0.08 & -36 & -36 \\
2000 & 2100 & 0.08 & -0.08 & -55 & -55 \\
1900 & 2000 & 0.23 & -0.23 & -86 & -86 \\
1800 & 1900 & 0.31 & -0.31 & -43 & -43 \\
1780 & 1800 & 0.05 & & -43 & -43 \\
& & & & & \\
Sum & & 22.80 & -4.37 & & \\
& & & & -20 & -23
\end{tabular}

(1) $\langle\Delta h\rangle$ is estimated as the mean elevation change of the grid points, and (2) $\langle\Delta h\rangle$ is determined from the volume change.

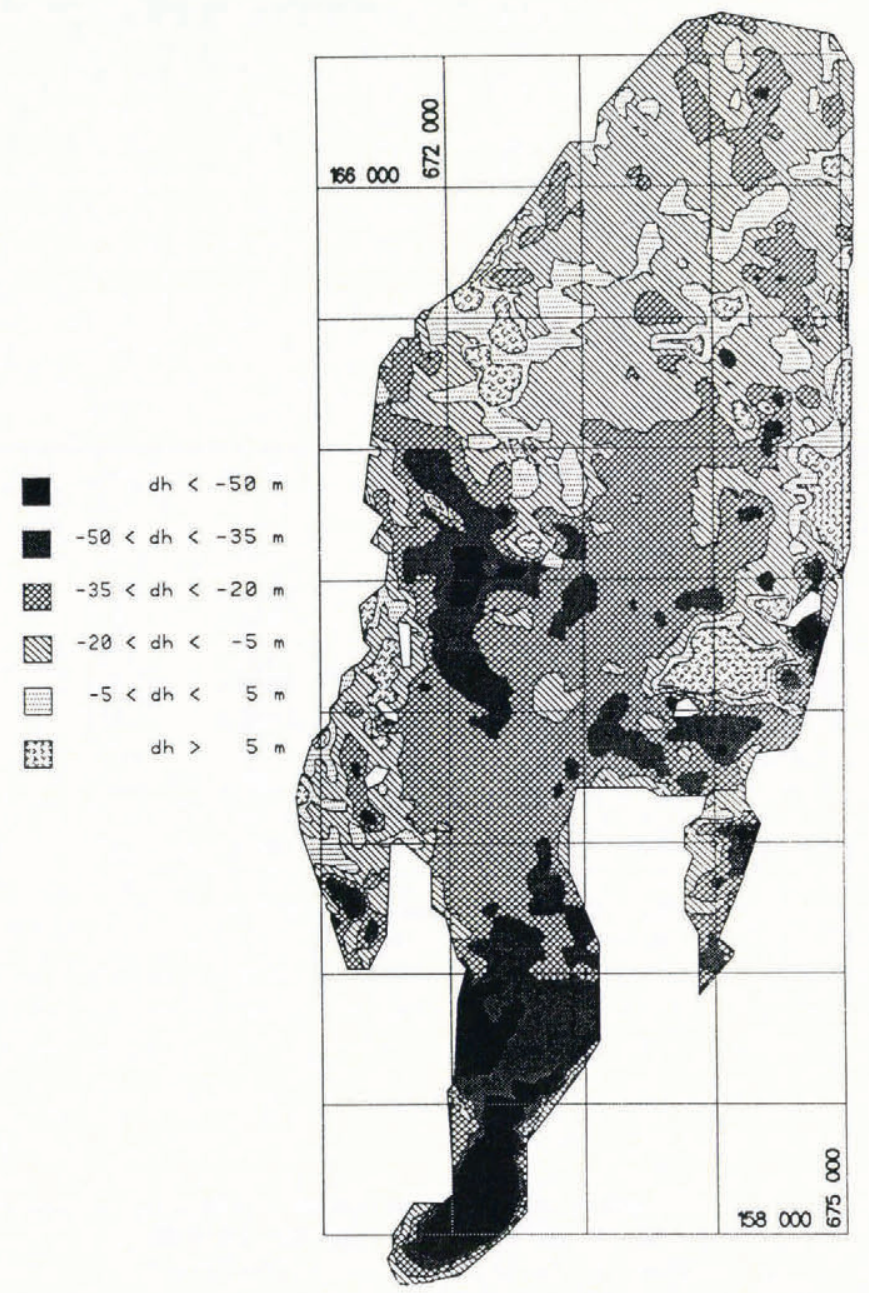

Fig. 6. The coordinates and thickness changes of Rhonegletscher between 1882 and 1969. 
where $\Delta z_{i}$ is the altitude interval $(100 \mathrm{~m})$ and $\Delta S_{i}$ is the area surrounded by the $i$ th contour lines of the glacier surfaces at different times. The values of $\Delta S_{i}$ in Equation (5) are measured per $100 \mathrm{~m}$ altitude interval for Rhonegletscher during 1882-1969 (see Fig. 2). The values of $\langle\Delta h\rangle$ for individual altitude intervals of Rhonegletscher during 1882-1969 calculated by Equations (4) and (5) are given in Table III. $\langle\Delta h\rangle$ for the entire glacier is $-23 \mathrm{~m}$. This value agrees fairly well with the value of $-20 \mathrm{~m}$ obtained by method I. In considering the accuracy of the maps, the mean elevation change during $1882-1969$ is within $23 \pm 5 \mathrm{~m}$.

\section{THE PT MODEL}

In order to determine the mass changes of this glacier during $1909 / 10-1978 / 79$ and for the period after 1982-83, it is necessary to estimate the annual mass balance for this period using the climatic data. The statistical parameterization of the PT models can be written as

$$
\langle b\rangle=\beta_{0}+\beta_{1}\langle P\rangle+\beta_{2}\langle T\rangle+\varepsilon
$$

where $b, P$, and $T$ are the specific net balance, precipiation, and air temperature, respectively, and \langle\rangle denotes their spatial mean over the entire glacier. $\beta_{0}, \beta_{1}$, and $\beta_{2}$ are the coefficients and $\varepsilon$ is the residual. Another form of Equation (4) is

$$
\langle b\rangle=\overline{\langle b\rangle}+\beta_{1}(\langle P\rangle-\overline{\langle P\rangle})+\beta_{2}(\langle T\rangle-\overline{\langle T\rangle})+\varepsilon
$$

with the same variables as in Equation (4) (a bar indicating the mean over the time period). $\beta_{1}$ (or $\beta_{1} \sigma\langle P\rangle / \beta_{0}$ ) represents the contribution of precipitation changes to $\langle b\rangle$ and $\beta_{2}$ (or $\beta_{2} \sigma\langle T\rangle / \beta_{0}$ ) that of temperature changes to $\langle b\rangle$. $\delta\langle P\rangle$ and $\sigma\langle T\rangle$ are the standard deviations of $\langle P\rangle$ and $\langle T\rangle$, respectively. Ideally, precipitation and temperature series of the glacierized region should be used in Equation (6). However, none exists for a long period. $P$ and $T$ for single stations nearest to the glacier are generally used (Martin, 1978; Vallon and Leiva, 1982; Holmlund, 1987; Letréguilly, unpublished).

The climatic stations Reckingen (lat. $46^{\circ} 28^{\prime} \mathrm{N}$., long. $08^{\circ} 15^{\prime}$ E., $1338 \mathrm{~m}$ a.s.1. and $9 \mathrm{~km}$ south of Rhonegletscher) and Andermatt (lat. $46^{\circ} 38^{\prime} \mathrm{N}$., long. $08^{\circ} 36^{\prime} \mathrm{E}$., $1442 \mathrm{~m}$ a.s.l. and $15 \mathrm{~km}$ north-east of this glacier) are selected for analysis due to the more significant correlations of their climatic elements with the $\langle b\rangle$ of Rhonegletscher in comparison with other neighbouring climatic stations. With various combinations of the climatic data for Reckingen and Andermatt (Schuepp, 1961; Uttinger, 1965; Weilenmann, unpublished), three PT models for the period $1884 / 85-1908 / 09$ and $1979 / 80-1981 / 82$ are established through multiple-regression analysis (see PT models Nos 1-3 in Table IV). The PT model used for extrapolation purposes in this study is:

$$
\langle b\rangle=5365+1.215\left\langle P_{\mathrm{a}}\right\rangle-587\left\langle T_{\mathrm{S}}\right\rangle
$$

with $\left\langle P_{\mathrm{a}}\right\rangle$ and $\left\langle T_{\mathrm{s}}\right\rangle$ being the mean annual precipitation and mean summer temperature for Reckingen and Andermatt. The units of $\langle b\rangle,\left\langle P_{\mathrm{a}}\right\rangle$, and $\left\langle T_{\mathrm{s}}\right\rangle$ are in $\mathrm{mm}$, and ${ }^{\circ} \mathrm{C}$, respectively. The multiple-correlation coefficient for Equation (7a) is 0.85 and it is significant at the $90 \%$ confidence limit. The standard deviation of the residuals of Equation (7a) is $354 \mathrm{~mm}$ w.e.

The ranges (the difference between the maximum and the minimum) of $\left\langle P_{\mathrm{a}}\right\rangle$ and $\left\langle T_{\mathrm{S}}\right\rangle$ for Reckingen and Andermatt are $1029 \mathrm{~mm}$ and $3.0^{\circ} \mathrm{C}$. It can be estimated from the regression coefficients of Equation (7a) that the contribution of $\left\langle T_{\mathrm{s}}\right\rangle$ to $\langle b\rangle$ is about 1.5 times that of $\left\langle P_{\mathrm{a}}\right\rangle$. By the standard deviations $\sigma_{\mathrm{p}}$ and $\sigma_{\mathrm{T}}$ of the climatic elements during the measurement period, it can also be seen from PT models Nos $1-3$ for Rhonegletscher (Table IV) that the influence of temperature changes on $\langle b\rangle$ is $1.3-1.8$ times that of the precipitation changes. Similar studies on some other alpine glaciers suggest that the influence of the temperature on $\langle b\rangle$ is usually of the same significance as or more important than that of the precipitation.

The air temperature is obviously very important in PT models for glaciers in maritime climatic regions such as the Alps. The significance of the air temperature to the massbalance processes has been recognized for a long time (Ahlmann, 1953). Under wet maritime climatic conditions, the sensible-heat flux and the long-wave radiation play a decisive role in the glacier ablation, and hence mass-balance processes. In the summer season, the net radiation $\left(90 \mathrm{~W} / \mathrm{m}^{2}\right)$ and sensible-heat flux $\left(81 \mathrm{~W} / \mathrm{m}^{2}\right)$ contribute almost equal amounts of energy to the heat input at the Rhonegletscher surface and nearly all of this heat input is used for melting (Funk, 1985). This is different from the situations of glaciers in dry continental climatic regions such as at Glacier No. 1 in the headwaters of the Urumqi River in Chinese Tian Shan, where $80-90 \%$ of the heat input is from net radiation with the remaining part $(10-20 \%)$ mostly from sensible heat. About $10 \%$ of the available heat input is used for evaporation and the remaining $90 \%$ for melting (Bai and Xie, 1965).

TABLE IV. REGRESSION MODELS OF THE SPECIFIC NET BALANCE $\langle b\rangle$ (IN mm w.e.), PRECIPITATION $P$ (IN mm), AND AIR TEMPERATURE $T$ (IN ${ }^{\circ} \mathrm{C}$ ) OF NEIGHBOURING CLIMATIC STATIONS FOR SOME ALPINE GLACIERS AND THE CORRELATION COEFFICIENTS $r$, COEFFICIENT $\left(\beta_{2} \sigma_{\mathrm{T}}\right) /\left(\beta_{1} \sigma_{\mathrm{P}}\right)$ SHOWS THE RELATIVE CONTRIBUTION OF TEMPERATURE TO THE NET BALANCE IN COMPARISON WITH PRECIPITATION

$\begin{array}{lllcc}\text { Glacier } & \text { Station } & \text { Regression formula } & r & \left(\beta_{2} \sigma_{\mathrm{T}}\right) /\left(\beta_{1} \sigma_{\mathrm{P}}\right) \\ \text { 1. Rhone } & \text { Reckingen } & \langle b\rangle=6320+1.094 P_{\mathrm{a}}-601 T_{\mathrm{S}} & 0.90 & 1.8 \\ \text { 2. Rhone } & \text { Andermatt } & \langle b\rangle=3650+0.929 P_{\mathrm{a}}-454 T_{\mathrm{S}} & 0.70 & 1.3 \\ \text { 3. Rhone } & \text { Reckingen and } & & & \\ & \text { Andermatt } & \langle b\rangle=5365+1.215\left\langle P_{\mathrm{a}}\right\rangle-587\left\langle T_{\mathrm{S}}\right\rangle & 0.85 & 1.4 \\ \text { 4. Sarenne } & \text { St. BErnhard } & \langle b\rangle=-1307+1.649 P_{\mathrm{a}}-333 T_{\mathrm{S}} & 0.80 & 0.6 \\ \text { 5. Gries } & \text { Sion } & \langle b\rangle=16024+1.021 P_{\mathrm{a}}-941 T_{\mathrm{ws}} & 0.88 & 5.0 \\ \text { 6. Limmern } & \text { Andermatt } & \langle b\rangle=4204+1.844 P_{\mathrm{wy}}-517 T_{\mathrm{S}} & 0.90 & 1.0 \\ \text { 7. Silvretta } & \text { Davos } & \langle b\rangle=1951+3.306 P_{\mathrm{a}}-448 T_{\mathrm{S}} & 0.86 & 0.8 \\ \text { 8. Hintereis } & \text { Vent } & \langle b\rangle=2568+2.337 P_{\mathrm{a}}-503 T_{\mathrm{ws}} & 0.82 & 1.5\end{array}$

The sources of mass-balance data of glaciers Nos 4-7 are Kasser (1967, 1973), Müller (1977), Haeberli (1985), and Haeberli and Müller (1988).

The periods for the regression analysis are: 1-3. 184/85-1908/09 and 1979/80-1981/82, 4. 1948/49$1984 / 85$, 5. $1961 / 62-1984 / 85,6$. $1947 / 48-1984 / 85$, 7. $1959 / 60-1984 / 85,8$. $1952 / 53-1984 / 85$.

$P_{\mathrm{a}}$ : annual precipitation (October-September); $P_{\text {wy }}$ : the winter half-year precipitation (October-April); $T_{S}:$ the mean summer temperature (May-September); $T_{\mathrm{ws}}:$ the weighted summer temperature $T_{\text {ws }}=$ $1 / 4\left(T_{\mathrm{VI}}+T_{\mathrm{VII}}+T_{\mathrm{VIII}}+0.5\left(T_{\mathrm{V}}+T_{\mathrm{IX}}\right)\right)$ where the subscripts VI, ... , and IX denote the month. 
The mean values of $\left\langle P_{\mathrm{a}}\right\rangle$ and $\left\langle T_{\mathrm{S}}\right\rangle$ for Reckingen and Andermatt during $1884 / 85-1908 / 09$ and $1979 / 80-1981 / 82$ are $1164 \mathrm{~mm}$ and $11.7^{\circ} \mathrm{C}$. Therefore, Equation (7a) can be written as:

$$
\langle b\rangle=-98+1.215\left(\left\langle P_{\mathrm{a}}\right\rangle-\overline{\left\langle P_{\mathrm{a}}\right\rangle}\right)-587\left(\left\langle T_{\mathrm{S}}\right\rangle-\overline{\left\langle T_{\mathrm{S}}\right\rangle}\right) .
$$

The mean $\overline{\langle b\rangle}$ in $\mathrm{mm}$ w.e./a (water equivalent per year) is therefore -98 from Equation (7a) and the measured $\langle b\rangle$ during $1884 / 85-1908 / 09$ and $1979 / 80-1981 / 82$ is $-95 \mathrm{~mm}$ w.e./a. The comparison with the result from Equation (7a) is shown in Figure 7. The mean and cumulative values of $\langle b\rangle$ for the period $1884 / 85-1908 / 09$ are $-130 \mathrm{~mm}$ w.e./a and $-3240 \mathrm{~mm}$ w.e. from the measured $\langle b\rangle$, and $-128 \mathrm{~mm}$ w.e./a and $-3197 \mathrm{~mm}$ w.e. as estimated by Equation (7a). Therefore, the $\langle b\rangle$ values calculated from Equation (7a) are close to the measured $\langle b\rangle$, although the results from PT models $1-3$ in Table IV all agree well with the measured $\langle b\rangle$.

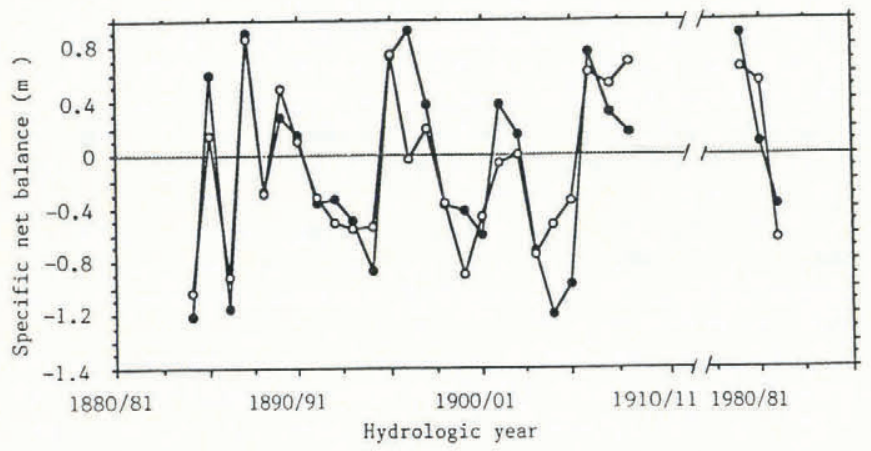

Fig. 7. Comparison of the measured specific net balance of Rhonegletscher (solid circles) with the values calculated by the PT model (open circles).

\section{THE RECONSTRUCTED SPECIFIC NET BALANCE}

To reconstruct the mass balance of the glacier by PT models, the statistical relationship established by the measured data is assumed to be valid for the period for which there are no mass-balance measurements (1909/10-1978/79 and 1982/83-1986/87). In fact, such statistical PT models do not remain strictly stable. The regression coefficients $\beta_{0}, \beta_{1}$, and $\beta_{2}$ will change with time. Therefore, $\langle b\rangle$ values estimated by using PT models may yield certain errors when long periods are considered.

The data for $P_{\mathrm{a}}$ in the years $1889-90,1896-97$, 1906-07, and $1929 / 30-1933 / 34$ and $T_{\mathrm{S}}$ in $1929-30$, $1931 / 32-1932 / 33$ at Reckingen are reconstructed on the basis of data from neighbouring stations (Weilenmann, unpublished). The observations at Reckingen ceased after 1981 and the data after that are reconstructed using those from Grimsel, another station near Rhonegletscher. Considering the regional variability of the climatic elements and the comparison with the measured mass balance, Equation (7a) is used for the reconstruction of $\langle b\rangle$ for Rhonegletscher.

The reconstructed specific net balance $\langle b\rangle$ of Rhonegletscher is given in Table V. In spite of some short periods with a positive mass balance, this glacier generally experienced mass loss after 1908-09, especially during the periods from the late 1920 s through the early 1960s, with the cumulative net balance being $-26 \pm 6 \mathrm{~m}$ w.e. at the $90 \%$ confidence level between $1882-83$ and $1986-87$ by the PT model (Fig. 8).

Errors introduced by the PT model calculation may be due to: (1) the inaccuracy of $\langle b\rangle$ during 1882/83-1908/09, upon which the PT models are based, and (2) the statistical property of the PT model and the inhomogeneity and the inaccuracy of $T_{S}$ and $P_{2}$. The cumulative specific net balance of Rhonegletscher is estimated statistically to be within $24 \pm 6 \mathrm{~m}$ w.e. at the $90 \%$ confidence level assuming that the $\langle b\rangle$ values for different years are independent from each other and that data for precipitation and temperature are free of error.
The great mass loss of Rhonegletscher since 1882-83 reflects the climatic warming after the end of the Little Ice Age. Some statistical values of the mean $\left\langle P_{\mathrm{a}}\right\rangle$ and $\left\langle T_{\mathrm{s}}\right\rangle$ for Reckingen and Andermatt, and those of $\langle b\rangle$ for Rhonegletscher in Table VI show a general increase in $\left\langle P_{\mathrm{a}}\right\rangle$ and $\left\langle T_{\mathrm{S}}\right\rangle$. A comparison of periods I $(1882-1920)$ and II $(1921-85)$ suggests that $\left\langle P_{\mathrm{a}}\right\rangle$ increased by $47 \mathrm{~mm}$ and $\left\langle T_{\mathrm{s}}\right\rangle$ by $0.9^{\circ} \mathrm{C}$. This leads to the relatively negative value of the reconstructed $\langle b\rangle(-48 \mathrm{~cm}$ w.e./a) for period II by the PT model. Small temperature changes obviously influence the mass changes greatly, while the influence of precipitation on the changes of mass balance is smaller.

It shows that Rhonegletscher mostly experienced mass loss since 1882-83. This can also be seen on other glaciers (Table VII) (Martin, 1978; Finsterwalder and Rentsch, 1980; Vallon and Leiva, 1982; Meier, 1985; Reynaud and others, 1986; Holmlund, 1987; Letréguilly, unpublished). The intense and continuous retreat of the Rhonegletscher front also suggests a negative value of the cumulative mass balance.

Annual precipitation $(\mathrm{mm}) /$ Summer temperature

$\left[{ }^{\circ} \mathrm{C}\right]$

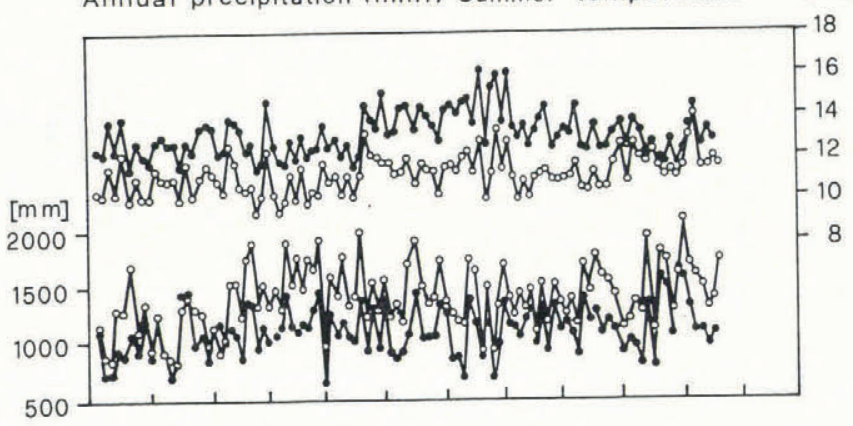

Specific net balance ( $m$ WE)

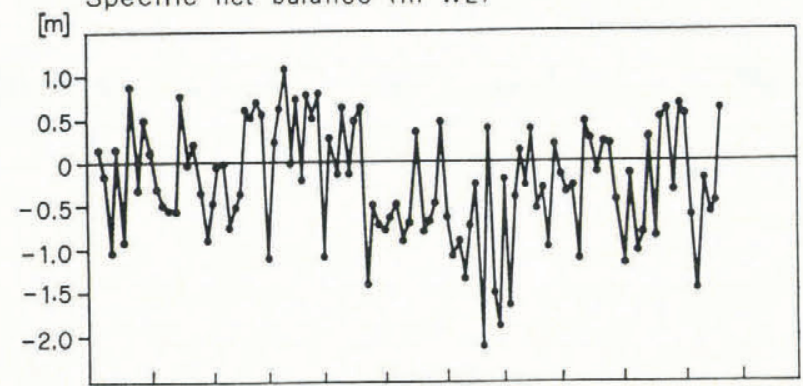

[m] Cumulative specific net balance (m WE)

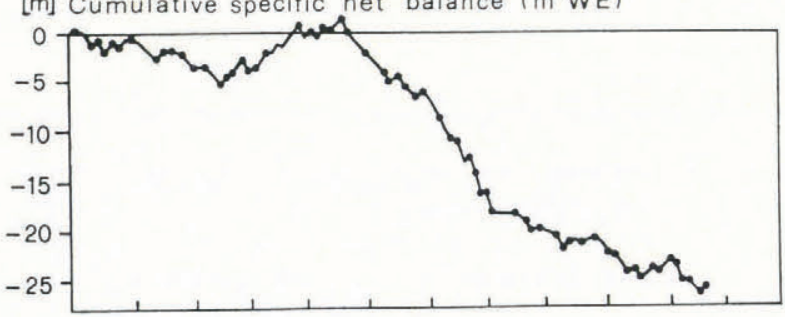

$[100 \mathrm{~m}]$ Front position

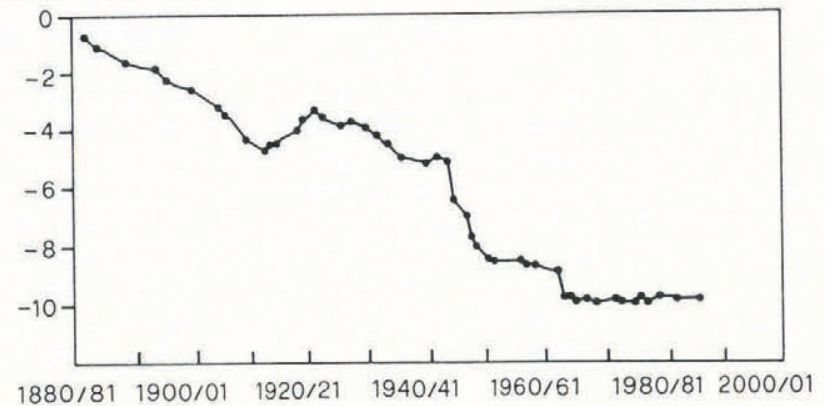

Fig. 8. Summer temperature and annual precipitation for Reckingen and Andermatt, and mass balance and front position of Rhonegletscher during 1882-1986. 1. Summer temperature and annual precipitation for Reckingen (solid circles) and Andermatt (open circles); 2. Calculated specific net balance of Rhonegletscher; 3. Cumulative specific net balance; 4. Changes of the frontal position of Rhonegletscher relative to 1881 . 
TABLE V. MEAN ANNUAL PRECIPITATION $\left\langle P_{\mathrm{a}}\right\rangle$ (IN mm) AND SUMMER TEMPERATURE $\left\langle T_{\mathrm{S}}\right\rangle$ $\left(\right.$ IN $\left.{ }^{\circ} \mathrm{C}\right)$ OF RECKINGEN AND ANDERMATT, AND THE CALCULATED SPECIFIC NET BALANCE $\langle b\rangle$ (IN cm w.e.) OF RHONEGLETSCHER

\begin{tabular}{|c|c|c|c|c|c|c|c|}
\hline Year & $\left\langle P_{a}\right\rangle$ & $\left\langle T_{\mathrm{S}}\right\rangle$ & $\langle b\rangle$ & Year & $\left\langle P_{\mathrm{a}}\right\rangle$ & $\left\langle T_{\mathrm{S}}\right\rangle$ & $\langle b\rangle$ \\
\hline $1882-83$ & 1107 & 11.2 & 14 & $1935-36$ & 1632 & 11.9 & 34 \\
\hline $1883-84$ & 778 & 11.0 & -17 & $1936-37$ & 1222 & 13.1 & -81 \\
\hline $1884-85$ & 769 & 12.5 & -103 & $1937-38$ & 1144 & 12.7 & -70 \\
\hline $1885-86$ & 1095 & 11.1 & 15 & $1938-39$ & 1187 & 12.4 & -47 \\
\hline $1886-87$ & 1065 & 12.9 & -91 & $1939-40$ & 1482 & 11.4 & 45 \\
\hline $1887-88$ & 1368 & 10.5 & 87 & $1940-51$ & 1259 & 12.9 & -64 \\
\hline $1888-89$ & 999 & 11.7 & -28 & $1941-42$ & 998 & 13.0 & -108 \\
\hline $1889-90$ & 1250 & 10.9 & 49 & $1942-43$ & 977 & 12.7 & -90 \\
\hline $1890-91$ & 879 & 10.8 & 10 & $1943-44$ & 883 & 13.2 & -134 \\
\hline $1891-92$ & 1124 & 12.0 & -31 & $1944-45$ & 1503 & 13.5 & -73 \\
\hline $1892-93$ & 880 & 11.9 & -52 & $1945-46$ & 1350 & 12.4 & -27 \\
\hline $1893-94$ & 747 & 11.6 & -56 & $1946-47$ & 842 & 14.5 & -212 \\
\hline $1894-95$ & 786 & 11.7 & -54 & $1947-48$ & 1326 & 11.2 & 38 \\
\hline $1895-96$ & 1344 & 10.6 & 75 & $1948-49$ & 749 & 13.2 & -150 \\
\hline $1896-97$ & 1401 & 12.1 & -3 & $1949-50$ & 1105 & 14.6 & -189 \\
\hline $1897-98$ & 1108 & 11.1 & 20 & $1950-51$ & 1481 & 12.6 & -20 \\
\hline $1898-99$ & 1132 & 12.1 & -36 & $1951-52$ & 1223 & 14.5 & -162 \\
\hline $1899-1900$ & 880 & 12.5 & -90 & $1952-53$ & 1138 & 12.2 & -40 \\
\hline $1900-01$ & 1096 & 12.2 & -46 & $1953-54$ & 1192 & 11.4 & 13 \\
\hline $1901-02$ & 1014 & 11.4 & -6 & $1954-55$ & 1208 & 12.1 & -27 \\
\hline $1902-03$ & 992 & 11.2 & 0 & $1955-56$ & 1322 & 11.2 & 37 \\
\hline $1903-04$ & 1296 & 13.1 & -75 & $1956-57$ & 995 & 12.1 & -52 \\
\hline $1904-05$ & 1264 & 12.6 & -52 & $1957-58$ & 1372 & 12.5 & -30 \\
\hline $1905-06$ & 1019 & 11.9 & -35 & $1958-559$ & 997 & 12.9 & -96 \\
\hline $1906-07$ & 1519 & 11.2 & 61 & $1959-60$ & 1358 & 11.6 & 18 \\
\hline $1907-08$ & 1586 & 11.5 & 52 & $1960-61$ & 1171 & 11.9 & -16 \\
\hline $1908-09$ & 1102 & 10.2 & 69 & $1961-62$ & 1150 & 12.1 & -34 \\
\hline $1909-10$ & 1290 & 10.9 & 57 & $1962-63$ & 1169 & 12.0 & -28 \\
\hline $1910-11$ & 1144 & 13.4 & -111 & $1963-64$ & 973 & 13.1 & -111 \\
\hline $1911-12$ & 1238 & 11.3 & 24 & $1964-65$ & 1487 & 11.5 & 46 \\
\hline $1912-13$ & 1178 & 10.5 & 64 & $1965-66$ & 1271 & 11.4 & 25 \\
\hline $1913-14$ & 1626 & 10.6 & 109 & $1966-67$ & 1451 & 12.4 & -12 \\
\hline $1914-15$ & 1294 & 11.9 & -1 & $1967-68$ & 1281 & 11.5 & 21 \\
\hline $1915-16$ & 1400 & 10.8 & 73 & $1968-69$ & 1300 & 11.5 & 20 \\
\hline $1916-17$ & 1288 & 12.2 & -20 & $1969-70$ & 1207 & 12.4 & -44 \\
\hline $1917-18$ & 1411 & 10.8 & 77 & $1970-71$ & 954 & 13.1 & -116 \\
\hline $1918-19$ & 1448 & 11.2 & 53 & $1971-72$ & 1037 & 11.6 & -15 \\
\hline $1919-20$ & 1650 & 11.2 & 77 & $1972-73$ & 1090 & 13.1 & -102 \\
\hline $1920-21$ & 768 & 12.6 & -109 & $1973-74$ & 976 & 12.6 & -81 \\
\hline $1921-22$ & 1392 & 11.6 & 25 & $1974-75$ & 1579 & 11.9 & 27 \\
\hline $1922-23$ & 1212 & 11.9 & -14 & $1975-76$ & 892 & 12.4 & -86 \\
\hline $1923-24$ & 1438 & 11.0 & 63 & $1976-77$ & 1632 & 11.6 & 51 \\
\hline $1924-25$ & 1158 & 11.8 & -15 & $1977-78$ & 1552 & 11.4 & 59 \\
\hline $1925-26$ & 1170 & 10.8 & 48 & $1978-79$ & 1118 & 12.1 & -35 \\
\hline $1926-27$ & 1650 & 11.5 & 62 & $1979-80$ & 1569 & 11.3 & 64 \\
\hline $1927-28$ & 1036 & 13.7 & -141 & $1980-81$ & 1776 & 11.9 & 54 \\
\hline $1928-29$ & 1387 & 12.9 & -52 & $1981-82$ & 1446 & 13.2 & -62 \\
\hline $1929-30$ & 1075 & 12.6 & -72 & $1982-83$ & 1278 & 14.2 & -144 \\
\hline $1930-31$ & 1421 & 13.4 & -77 & $1983-84$ & 1228 & 12.0 & -21 \\
\hline $1931-32$ & 1022 & 12.4 & -64 & $1984-85$ & 1078 & 12.4 & -60 \\
\hline $1932-33$ & 1050 & 12.1 & -49 & $1985-86$ & 1169 & 12.4 & -46 \\
\hline $1933-34$ & 1002 & 12.8 & -90 & $1986-87$ & 1673 & 11.6 & 59 \\
\hline $1934-35$ & 1329 & 13.1 & -71 & & & & \\
\hline
\end{tabular}

TABLE VI. THE MEAN, RANGE $R a$, AND STANDARD DEVIATION $\sigma$ OF THE MEAN ANNUAL PRECIPITATION $\left\langle P_{\mathrm{a}}\right\rangle$ (IN $\mathrm{mm}$ ), AND MEAN SUMMER TEMPERATURE $\left\langle T_{\mathrm{S}}\right\rangle$ (IN $\left.{ }^{\circ} \mathrm{C}\right)$ OF RECKINGEN AND ANDERMATT, AND OF THE SPECIFIC NET BALANCE $\langle b\rangle$ (IN mm w.e.) OF THE RHONEGLETSCHER CALCULATED BY THE PT MODEL

\begin{tabular}{|c|c|c|c|c|c|c|c|c|c|}
\hline & \multirow[b]{2}{*}{ Period } & \multicolumn{3}{|c|}{$\langle P\rangle$} & \multicolumn{3}{|c|}{$\left\langle T_{\mathrm{s}}\right\rangle$} & \multicolumn{2}{|r|}{$\langle b\rangle$} \\
\hline & & Mean & $R a$ & $\sigma$ & Mean & $R a$ & $\sigma$ & Mean & $R a$ \\
\hline 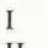 & $1882-1920$ & 1162 & 903 & 247 & 11.6 & 3.2 & 0.8 & -10 & 2200 \\
\hline II & $1921-60$ & 1211 & 901 & 209 & 12.5 & 3.9 & 0.9 & -480 & 2622 \\
\hline III & $1961-85$ & 1282 & 884 & 247 & 12.2 & 3.0 & 0.7 & -230 & 2003 \\
\hline
\end{tabular}


TABLE VII. MEAN MASS OR THICKNESS CHANGES $\overline{\langle b\rangle}(\mathrm{OR}\langle\overline{\langle h\rangle})$ OF SOME GLACIERS (IN cm w.e./a) DURING THE CORRESPONDING PERIOD

\begin{tabular}{|c|c|c|c|c|c|c|c|c|c|}
\hline & 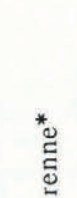 & $\begin{array}{l}\text { d } \\
\frac{0}{0} \\
\frac{0}{0} \\
\frac{0}{00} \\
0 \\
0 \\
0\end{array}$ & 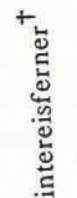 & 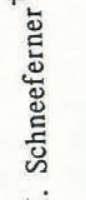 & 岕 & + & 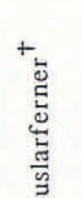 & 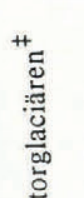 & ఝ \\
\hline & $\overline{\mathscr{H}}$ & $\bar{\alpha}$ & $\bar{I}$ & $\dot{z}$ & $\dot{v}$ & $>$ & 0 & $\ddot{n}$ & 3 \\
\hline$\overline{\langle b\rangle}, \overline{\langle\Delta h\rangle}$ & -49 & -25 & -46 & -39 & -63 & -21 & -29 & -25 & -38 \\
\hline from & 1882 & 1882 & 1894 & 1892 & 1892 & 1889 & 1889 & 1878 & 1900 \\
\hline to & 1975 & 1986 & 1979 & 1979 & 1979 & 1979 & 1979 & 1986 & 1961 \\
\hline
\end{tabular}

Data sources: * Martin (1978); † Finsterwalder and Rentsch (1980); ${ }^{\ddagger}$ Holmlund (1987); and § Meier (1985). WG specifies about 25 glaciers and small ice caps in 13 regions. 〈〉 denotes the mean over the entire glacier and a bar the mean over the given period.

The retreat of this glacier since the end of the Little Ice Age has been interrupted only by some short periods of advance (Fig. 8). It retreated by $970 \mathrm{~m}$ during 1882-1986, corresponding to a mean rate of $-9.4 \mathrm{~m} / \mathrm{a}$. During $1882-1969$, the ice-covered area decreased by $4.37 \mathrm{~km}^{2}$ and the volume by $4.71 \times 10^{8} \mathrm{~m}^{3}$. The reconstructed massbalance history of the glacier agrees with this trend.

\section{SUMMARY}

The mass balance of Rhonegletscher for the period $1884 / 85-1984 / 85$ was examined on the basis of measurements during 1884/85-1908/09 and 1979/80-1981/82, and on estimation by PT models: the regression models of the mean specific net balance over the entire glacier $\langle b\rangle$ and the climatic elements. The reconstructed $\langle b\rangle$ during $1884 / 85-1968 / 69$ from the PT model was compared with the ice-thickness change of the same period based on the cartographic method. For Rhonegletscher during 1882/83-1968/69, the cumulative $\langle b\rangle$ is $-24 \pm 6 \mathrm{~m}$ w.e. by the PT model, while the mean thickness change is $-23 \pm 5 \mathrm{~m}$ by the cartographic method. The uncertainty ranges of the results from these two methods overlap each other.

Rhonegletscher has experienced relatively great mass loss since the end of the Little Ice Age. The cumulative specific net balance is $-3.4 \mathrm{~m}$ w.e. during $1884 / 85-1908 / 09$ according to the stake measurements and $-26 \pm 6 \mathrm{~m}$ w.e. during 1882/83-1986/87 according to the PT models. Some short periods of positive $b$ are found in the late $1880 \mathrm{~s}$, the mid-1890s, the late $1900 \mathrm{~s}$ to the late $1910 \mathrm{~s}$, and in the late 1970s. The other periods in between show negative $b$, especially during the period from the late 1920 s through the early 1960s with maximum mass loss in the 1940s.

The influence of summer temperature on the mass balance is of more importance than that of precipitation for Rhonegletscher. This seems to apply also to other alpine glaciers under wet maritime climatic conditions. The temporal change of $\langle b\rangle$ for Rhonegletscher reflects a general trend of warming after the end of the Little Ice Age with the warmest period from the late 1920s to the early 1950 s, especially in the 1940 s.

The negative mass balance partly explains the continuous retreat of this glacier since the end of the Little Ice Age. Rhonegletscher retreated $970 \mathrm{~m}$ during 1882-1986, which is $9 \%$ of its length. For the period 1882-1969, this glacier decreased by $19 \%$ of the ice-covered area, by $20 \%$ of its thickness, and by $27 \%$ of its volume.

\section{ACKNOWLEDGEMENTS}

The discussions with Professor A. Ohmura, Dr W. Haeberli, and H. Jensen are appreciated. Professor M. Kuhn and G. Markl of Universität Innsbruck provided the mass- balance data for Hintereisferner and the climatic data for Vent. Professor A. Ohmura, Dr W. Haeberli, M. Aellen, Dr L. Braun, and $\mathrm{Dr} \mathrm{H}$. Blatter read the manuscript, and the authors profited from many of their valuable comments and suggestions. Mrs S. Braun corrected the English text. We should also like to thank the anonymous referee who critically reviewed the manuscript.

\section{REFERENCES}

Ahlmann, H.W. 1953. Glacier variations and climatic fluctuations. New York, American Geographical Society. (Bowman Memorial Lectures, Ser. 3.)

Bai, Z. and W. Xie. 1965. Heat balance on an open ice surface during a melting season of Glacier No. 1 in the head of Urumqi River, Tianshan. In Shi Yafeng, ed. Glaciological and hydrological investigations in the Urumqi River, Tianshan. Beijing, Science Press, 74-82.

Bernath, A. Unpublished. Gedanken und Beiträge zum Wasserhaushalt eines teilweise vergletscherten Einzugsgebietes in den Schweizer Alpen. (Diplomarbeit, Eidgenössische Technische Hochschule, Zürich. Geographisches Institut, 1980.)

Coaz, J. 1885. Jahresberichte über die RhonegletscherVermessung. Jahrbuch des Schweizerischen Alpen-Clubs.

Finsterwalder, R. 1954. Photogrammetry and glacier research with special reference to glacier retreat in the eastern Alps. J. Glaciol., 2(15), 306-315.

Finsterwalder, R. and H. Rentsch. 1980. Zur Höhenänderung von Ostalpengletschern im Zeitraum 1969-1979. Z. Gletscherkd. Glazialgeol., 16(1), 111-115.

Funk, M. 1985. Räumliche Verteilung der Massenbilanz auf dem Rhonegletscher und ihre Beziehung zu Klimaelementen. Zürcher Geogr. Schr. 24.

Haeberli, W. 1985. Fluctuations of glaciers 1975-1980. (Vol. IV.) Paris, International Association of Hydrological Sciences/UNESCO.

Haeberli, W. and P. Müller. 1988. Fluctuations of glaciers 1980-1985. (Vol. V.) Wallingford, Oxfordshire, International Association of Hydrological Sciences; Nairobi, United Nations Environment Programme; Paris, UNESCO.

Haeberli, W. and J. Schweizer. 1988. Rhonegletscher 1850: eismechanische Ueberlegungen zu einem historischen Gletscherstand. Eidg. Tech. Hochschule, Zürich. Versuchsanst. Wasserbau, Hydrol. Glaziol. Mitt. 94, 59-70. Haeberli, W., H.-P. Wächter, W. Schmid, and C. Sidler. 1983. Erste Erfahrungen mit dem U.S.-Geological-SurveyMonopuls-Radioecholot im Firn, Eis und Permafrost der Schweizer Alpen. Z. Gletscherkd. Glazialgeol., 19(1), 61-72.

Haefeli, R. 1962. The ablation gradient and the retreat of a glacier tongue. International Association of Scientific Hydrology Publication 58 (Symposium at Obergurgl 1962 Variations of glaciers), 49-59. 
Hagenbach-Bischoff, E. 1894-1910. Jahresberichte über die Rhonegletscher-Vermessung. Verh. Schweiz. Naturforsch. Ges.

Heim, A. 1910-1915. Jahresberichte über die Rhonegletscher-Vermessung. Verh. Schweiz. Naturforsch. Ges.

Held, L. 1889. Die Rhonegletscher-Vermessung, verglichen mit Vermessungen anderer Alpengletscher. Jahrbuch des Schweizerischen Alpen-Clubs.

Hoinkes, H. 1970. Methoden und Möglichkeiten von Massenhaushaltsstudien auf Gletschern. Z. Gletscherkd. Glazialgeol., 6(1-2), 37-90.

Holmlund, P. 1987. Mass balance of Storglaciären during the 20th century. Geogr. Ann., 69A(3-4), 439-447.

Kasser, P. 1967. Fluctuations of glaciers, 1959-1965. [Vol. 1.] Paris, International Association of Scientific Hydrology/UNESCO.

Kasser, P. 1973. Fluctuations of glaciers 1965-1970. [Vol. 2.] Paris, International Association of Hydrological Sciences.

Kasser, P., M. Aellen, and H. Siegenthaler. 1986. Die Gletscher der Schweizer Alpen 1977/78 und 1978/79. Zürich, Gletscherkommission der Schweizerischen Naturforschenden Gesellschaft. (Glaziologisches Jahrbuch 99 and 100.)

Letréguilly, A. Unpublished. Bilans de masse des glaciers alpins: méthodes de mesure et répartition spatiale-temporelle. (Ph.D. thesis, Université de Grenoble, 1984.)

Martin, S. 1978. Analyse et reconstitution de la série des bilans annuels du glacier de Sarennes, sa relation avec les fluctuations du niveau de trois glaciers du Massif du Mont-Blanc (Bossons, Argentière, Mer de Glace). $Z$. Gletscherkd. Glazialgeol., 13(1/2), 1977, 127-153.

Mayo, L.R., M.F. Meier, and W.V. Tangborn. 1972. A system to combine stratigraphic and annual mass-balance systems: a contribution to the International Hydrological Decade. J. Glaciol., 11(61), 3-14.

Meier, M.F. 1963. Proposed definitions for glacier mass budget terms. J. Glaciol., 4(35), 649-650.

Meier, M.F. 1985. Mass balance of the glaciers and small ice caps of the world. In Glaciers, Ice Sheets and Sea Level: Effect of a $\mathrm{CO}_{2}$-Induced Climatic Change. Report of a workshop held in Seattle, Washington. September 13-15, 1984. Washington, DC, United States Department of Energy, 139-144.

Meier, M.F. and W.V. Tangborn. 1965. Net budget and flow of South Cascade Glacier, Washington, J. Glaciol., 5(41), 547-566.

Mercanton, P.L. 1916. Vermessungen am Rhonegletscher. Denksch. Schweiz. Naturforsch. Ges. 52.

Müller, F. 1977. Fluctuations of glaciers 1970-1975. (Vol. III.) Paris, International Association of Hydrological Sciences/UNESCO.

Müller, F., T. Caflisch, and G. Müller 1976. Firn und Eis der Schweizer Alpen. Gletscherinventar. Eidg. Tech.
Hochschule, Zürich. Geogr. Inst. Publ. 57/57a.

Müller, F., and 6 others. 1980. Combined ice, water and energy balances of a glacierized basin of the Swiss Alps - the Rhonegletscher project. Geogr. Helv., 35(5), 57-69.

Müller, P. 1988. Parametrisierung der Gletscher-KlimaBeziehung für die Praxis: Grundlagen und Beispiele. Eidg. Tech. Hochschule, Zürich. Versuchsanst. Wasserbau, Hydrol. Glaziol. Mitt. 95.

Ohmura, A. 1988. Role of glaciers in a climatic change Eidg. Tech. Hochschule, Zürich. Versuchsanst. Wasserbau, Hydrol. Glaziol. Mitt. 94, 109-126.

Østrem, G. and A. Stanley. 1966. Glacier mass balance measurements; a manual for field work. Ottawa, Canadian Department of Energy, Mines and Resources; Oslo Norwegian Water Resources and Electricity Board.

Reinhardt, W. and H. Rentsch. 1986. Determination of changes in volume and elevation of glaciers using digital elevation models for the Vernagtferner, Ötztal Alps, Austria. Ann. Glaciol., 8, 151-155.

Reynaud, L., M. Vallon, and A. Letréguilly. 1986. Mass-balance measurements: problems and two new methods of determining variations. J. Glaciol., 32(112), 446-454.

Röthlisberger, H. 1963. The Rhone Glacier surveys. Bulletin of the International Association of Scientific Hydrology, VIII ${ }^{\mathrm{e}}$ Année, 2, 119-121.

Rütimeyer, L. 1880-1881. Ein Blick auf die Geschichte der Gletscherstudien in der Schweiz. Die Hauptresultate der Rhonegletscher-Vermessung. Jahrbuch des Schweizerischen Alpen-Clubs.

Rütimeyer, L. 1881-1884. 1886-1888. Jahresberichte über die Rhonegletscher-Vermessung. Jahrbuch des Schweizerischen Alpen-Clubs.

Schuepp, M. 1961. Lufttemperatur. Klimatologie der Schweiz, Heft C. Annalen der Schweizerischen Meteorologischen Zentralanstalt, 1960. (Beilage.)

Tangborn, W. 1980. Two models for estimating climateglacier relationships in the North Cascades, Washington, U.S.A. J. Glaciol., 25(91), 3-21.

Uttinger, H. 1965. Niederschlag. Klimatologie der Schweiz, Heft E. Annalen der Schweizerischen Meteorologischen Zentralanstalt, 1964. (Beilage.)

Vallon, M. and J.C. Leiva. 1982. Bilan de masse et fluctuations récentes du Glacier de Saint-Sorlin (Alpes Françaises). Z. Gletscherkd. Glazialgeol., 17(2), 1981, 143-167.

Waechter, H. P. Unpublished. Eisdickenmessungen auf dem Rhonegletscher - ein Versuch mit Radio-Echo Sounding. (Diplomarbeit, Eidgenössische Technische Hochschule, Zürich. Geographisches Institut, 1981.)

Weilenmann, U. Unpublished. Der Rhonegletscher und sein Vorfeld. (Diplomarbeit. Eidgenössische Technische Hochschule, Zürich. Geographisches Institut, 1979.) 